\title{
The Effect Of Distributed Earnings And Size Of The Firm To Its Dividend Policy: Some Greek Data
}

\author{
Nikolaos Eriotis, (Email: nikolaos.eriotis@aueb.gr), National University and University of Athens, Greece
}

\begin{abstract}
The objective of this paper is to examine the corporate dividend policy for the Greek market. In a series of studies, concerning the Greek market, Vasiliou \& Eriotis test and improve, using a panel of data, the classical study of John Lintner who explains the amount dividend paid by firms using the earnings of the firm plus an adjustment according to the dividend paid the year before. This paper is an extension of Vasiliou \& Eriotis' work that test the assumption that firms set their dividend policy not only by the net distributed earnings, but also by the change from the last year's dividend, the change from the last year's distributed earnings and the size of the firm. This model is applied on a panel sample of a large number of firms listed on the Athens Stock Exchange for the period 1996 - 2001. The hypothesis that is tested in this paper is that the dividend at time $t$ depends upon the distributed earnings at time $t$, the size of the firm and changes in dividend and distributed earnings from the last year ( $t-1)$. The empirical results verified the hypothesis that the Greek companies prefer to distribute, each year a rather constant dividend, which they adjust from year to year according to their distributed earnings and size.
\end{abstract}

\section{INTRODUCTION}

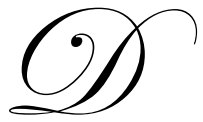

uring the last years a series of studies concerning the dividend policy in the Greek market have been performed. The motivation for these studies is the international extensive researches about factors that might be important in determining firm's dividend policy. There are many reasons explaining why dividend policy is so interesting. One reason is that the dividend policy of the firm affects its capital structure, since the retained earnings intent to fund the firm. Otherwise, the firm has to raise funds by issuing new debt. Consider the case where the dividend payment is increased, then fewer funds are available internally for financing investments and consequently additional equity capital is needed, thus the company has to issue new common stock. In the real world, firms choose to raise funds instead of retain bigger portion of their earnings. Another reason is that a company's dividend decision may change the value of its stock.

During the last fifty years, a series of empirical and theoretical works have been conducted. Summarizing all these works, there are three dominating views. The first one suggests that an increase in dividend payout affects positively the market value of the firm ${ }^{1}$. The second argues that a positive change in the dividend decreases the firm's value ${ }^{2}$. Finally, the third one claims that dividend policy does not affect the market value of the firm ${ }^{3}$. However, the empirical evidence on the determinants of corporate dividend policy is, unfortunately, very mixed ${ }^{4}$.

This paper continues the analysis of dividend policy for the Greek market and tests the effect of the size of the firm and the changes in its distributed earnings. The empirical investigation is performed in a panel of data from

\footnotetext{
${ }^{1}$ See Gordon (1963), and Lintner (1962).

${ }^{2}$ See Lintzenberger and Ramaswamy (1979).

${ }^{3}$ See Miller and Modigliani (1961).

${ }^{4}$ For more information see Frankfurter and Wood, Jr. (2002), Allen and Michaely (1995), Barclay, Smith and Watts (1995), and Short, Zhang, and Keasey (2002).
} 
a sample of the companies listed in the Greek stock market during the period 1996 - 2001. This paper is organized as follows. Section 2 describes briefly the empirical models that explain how corporate managers decide on dividend payments and presents the main findings of the relevant literature. Section 3 discusses the data and the variables employed in the analysis. Section 4 reports the model that is designed to provide a basis for assessing the relevant importance of the various factors explaining the corporate dividend policy. Section 5 provides the results of the empirical analysis. Finally, section 6 presents the conclusions.

\section{MODELS OF DIVIDEND POLICY}

In a characteristic study, John Lintner (1956) conducted a series of interviews with corporate managers about dividend policies of their companies. The total number of companies that he used was 600 from which he finally has chosen only 28 , to survey and interview. In his study, Lintner made a number of important observations concerning the dividend policies of these companies. One of the most important conclusions is that companies have a long-run target dividend payout ratio. That meant that companies aim to distribute, in the long run, a constant portion of their earnings each year. Another interesting remark of Lintner's study concerns the managers that proved to be more interested on changes on dividend than on absolute levels. Additionally, managers avoid changing their dividend policy if they were not certain that they will be able to keep the new policy constant for a reasonable period. That is to say that managers avoid changing the companies' dividend policy very often since it is likely to give a negative signal to investors as uncertainty increases.

In his empirical analysis, Lintner developed a partial adjustment model that captures the above findings. According to Lintner, each firm $i$ has a target dividend payout ratio $\left(r_{i}\right)$. Using this payout ratio, Lintner, computed the target dividend at time $t\left(D_{i t}{ }^{*}\right)$ as a proportion of the real earnings of the firm i at time $t\left(E_{i t}\right)$, i.e. $D_{i t}{ }^{*}=r_{i} E_{i t}$. In real world the dividend, which the firm finally pays, at time $t,\left(D_{i t}\right)$ differs from the target one $\left(D_{i t}{ }^{*}\right)$. Thus, it is more reasonable to model the change between the actual dividend at time $t$ and time $t-1$, instead of the actual dividend at time $t$ only. Taking the change in actual dividends into account, it is realistic and consistent with the long-run target payout ratio, to assume that the actual change in dividend at time $t,\left(D_{i t}-D_{i, t-1}\right)$, equals to a constant portion $\left(\alpha_{i}\right)$ plus the speed with which the dividend, at time $t-1$, has adjusted to the target dividend at time $t,\left(D_{i t}{ }^{*}-D_{i, t-1}\right)$. Since the target dividend at time $t$ is a proportion of the real earnings at time $t$, the final model is as follows:

$$
D_{i t}-D_{i, t-1}=a_{i}+c_{i} r_{i} E_{i t}-c_{i} D_{i, t-1}
$$

where $D_{i t}=$ the actual dividend payment during period $t, E_{i t}=$ the earnings of the firm during period $t, c_{i}=$ the adjustment factor (which indicates the speed with which the dividend, at time $\mathrm{t}-1$, has adjusted to the optimal target dividend at time $\mathrm{t}$ ), and $\mathrm{r}_{\mathrm{i}}=$ the target payout ratio. This theoretical model can be estimated using the following econometric model:

$$
\Delta D_{i t}=a_{i}+\beta_{1} E_{i t}+\beta_{2} D_{i, t-1}+\varepsilon_{i t}
$$

where $\Delta D_{i t}=$ the change in dividend from time $t-1$ to time $t$, for the firm i, $\beta_{1}$ represents the product $c_{i}$ times $r_{i}$ of the theoretical model, $\beta_{2}=$ the variable $\mathrm{c}_{\mathrm{i}}$ of the theoretical model with negative sign (that is, $\beta_{2}=-\mathrm{c}_{\mathrm{i}}$ ), and $\varepsilon_{\mathrm{it}}=$ the error of the model ${ }^{5}$. Lintner's estimation of the above model appeared fairly good, explaining $85 \%$ of the dividend changes in his sample of companies.

Fama and Babiak (1968) undertook a more comprehensive study of Lintner model's performance. Their starting point was the work of Lintner (1956). Their sample consists of 392 industrial firms over the period 1946 through 1964. Fama and Babiak tested the Lintner's model with their data and methodology and found that it performed well but it can be improved by introducing, as an additional explanatory variable, the earnings from the previous year without the constant term. An alternative behavioral justification often used in the literature to derive

\footnotetext{
${ }^{5} \beta_{1}=c_{i} r_{i} \Rightarrow r_{i}=\left(\beta_{1} / c_{i}\right) \Rightarrow r_{i}=\left(-\beta_{1} / \beta_{2}\right)$.
} 
equation (2) is the adaptive expectations model ${ }^{6}$. This model assumes that the dividend at time $t$ is given by a proportion $\left(\kappa_{\mathrm{i}}\right)$ of the long-run expected earnings at time $t\left(\mathrm{E}_{\mathrm{it}}{ }^{*}\right)$ plus a disturbance term $\left(\mathrm{v}_{\mathrm{it}}\right)$.

$$
D_{i t}=\kappa_{i} E_{i t}^{*}+v_{i t}
$$

In addition, the model assumes that the change at $\mathrm{t}$ in long-run expected earnings $\left(\mathrm{E}_{\mathrm{it}}{ }^{*}-\mathrm{E}_{\mathrm{i}, \mathrm{t}-\mathrm{t}}{ }^{*}\right)$, can be expressed as a proportion $\left(\lambda_{\mathrm{i}}\right)$ of the change between the actual earnings at time $t$ and the expected long-run earnings at time $t-1\left(\mathrm{E}_{\mathrm{it}}\right.$ $\left.-\mathrm{E}_{\mathrm{i}, \mathrm{t}-1}{ }^{*}\right)$; that is,

$$
E_{i t}^{*}-E_{i, t-1}^{*}=\lambda_{i}\left(E_{i t}-E_{i, t-1}^{*}\right)
$$

But if the successive earning changes are independent, the optimal value of $\lambda_{\mathrm{i}}$ is one (full adjustment). Thus, the final theoretical model suggests that the change in dividend $\left(D_{i t}-D_{i, t-1}\right)$ is equal to a constant portion $\left(\alpha_{i}\right)$ plus the proportion $\left(\kappa_{\mathrm{i}}\right)$ of the actual earnings $\left(\mathrm{E}_{\mathrm{it}}\right)$ minus $\lambda_{\mathrm{i}}$ times the dividend at time $\mathrm{t}-1$ (note that the optimal $\lambda$ is one):

$$
D_{i t}-D_{i, t-1}=a_{i}+\kappa_{i} E_{i t}-D_{i, t-1}+v_{i t}
$$

However, Fama and Babiak (1968) claim that their estimations suggest that the adaptive expectations appears to be an inappropriate specification to their sample.

As far as the dividend policy in the Greek market is concerned, there is a number of papers testing alternative dividend policy models. Patsouratis (1989) investigated empirically the Greek corporate dividend behavior employing analysis of covariance. The basis of this research is the classic work of Brittain (1964). His sample consists of 25 firms and covers the period 1974 - 1983. Next, Joannos and Filippas (1997) examined the dividend policy of 34 firms listed in the Athens Stock Exchange during the period 1972 - 1988. Their empirical results lead to the general conclusion that Lintner's model best describes the dividend policy of the Greek firms. Current profits constitute the most important variable that tends to influence the change in dividends while the previous period dividends tend to also significantly influence the change in the dividend policy of the firms.

This paper is based on the work of Vasiliou \& Eriotis (2003) and Eriotis \& Vasiliou (2003). Vasiliou and Eriotis (2003) test the model of Lintner and suggest two different versions that improve the original model introduced by Lintner. In their first version of the Lintner's model, they consider as dependent variable the change in dividend between time $t$ and time $t-1$ and as independent variables the change in the earnings of the firm between time $t$ and $t-1$ and the change in dividend between time $t-1$ and $t-2$ :

$$
\Delta D_{i t}=a_{i}+\beta_{1} \Delta E_{i t}+\beta_{2} \Delta D_{i, t-1}+\varepsilon_{i t}
$$

where $D_{i t}$ is the dividend of the firm $i$ at time $t, E_{i t}$ is the net income of the firm $i$ available to stockholders at time $t$, $\Delta \mathrm{D}_{\mathrm{it}}\left(=\mathrm{D}_{\mathrm{it}}-\mathrm{D}_{\mathrm{i}, \mathrm{t}-1}\right)$ is the change between the dividend at time $\mathrm{t}$ and time $\mathrm{t}-1$, for the firm $\mathrm{i}, \Delta \mathrm{E}_{\mathrm{it}}\left(=\mathrm{E}_{\mathrm{it}}-\mathrm{E}_{\mathrm{i}, \mathrm{t}-1}\right)$ the change in the net income available to stockholders, at time $t$ and time $\mathrm{t}-1$, and $\varepsilon_{\mathrm{it}}$ is the error at time $\mathrm{t}$.

The next empirical model that they test considers the same variables, dependent and independent, but this time without the changes between time $\mathrm{t}$ and $\mathrm{t}-1$ :

$$
D_{i t}=a_{i}+\beta_{1} E_{i t}+\beta_{2} D_{i, t-1}+\varepsilon_{i t}
$$

The findings of Vasiliou and Eriotis (2003) suggest that the Greek firms follow a discrete dividend policy. That is, the dividend payout of a firm depends upon the firm's long-run target dividend that is adjusted according to the net earnings of the firm.

\footnotetext{
${ }^{6}$ For a discussion, see Brittain (1966), pp. 27-31.
} 
Eriotis and Vasiliou (2003) followed the similar process and analyze the effect of sales in a model like the one presented in equation 4 . Their results support that firms adjust their dividend according to their earnings and they are not willing to change their dividend policy in the short - run. Additionally, the introduction of sales in the empirical analysis improve the estimations and provide an indication that successful sales of a firm can improve the amount of distributed dividend.

This paper examines the explanatory power of distributed earnings and size of the firm. According to this hypothesis, the decision to distribute dividend is more proper to be explained not by the earnings of the firm but with the combination of current distributed earnings and size of firm. The size of firm is represented by the current sales of the firm and includes both the risk of company and the related bankruptcy cost ${ }^{7}$. Large companies are more independent and less risky than small firms, which make them more attractive to investors. Additionally, the management team of large companies is more willing to pay higher dividends, than smaller firms. In order to test the previous result of Vasiliou and Eriotis for the Greek market (that Greek firms have a long run target dividend payout ratio) two variables are included. The first one is the changes in dividend between year t and t-1 and the second one is the changes in distributed earnings between year $\mathrm{t}$ and $\mathrm{t}-1$.

\section{DATA AND VARIABLES}

The empirical investigation conducted for a large sample of the companies listed in the Athens Stock Exchange market during the period 1996 - 2001. For a firm to be included in the sample, two criteria had to be met. First, the firm had to be listed in the Stock Exchange market for the whole of the period under consideration. Second, the firm would be required to be listed in the year 1995. This condition was imposed to ensure that dividend policy was not distorted by the effects of a recent official listing. The final sample consists of 149 firms in a 5 year period; that is, a panel of data with 718 observations, since some data were missing.

In order to examine empirically the dividend models discussed in the previous section, the key variables of interest are the: measures of dividends (D), distributed earnings (DE), sales (S) and changes in this year's distributed earnings and dividend from this year to the year before $(\triangle \mathrm{DE}$ and $\Delta \mathrm{D})$. These variables were derived from data collected from the financial database of the Athens Stock Exchange. Dividends $\left(\mathrm{D}_{\mathrm{i}, \mathrm{t}}\right)$ are calculated as the total amount of dividends of the firm $i$ at time $t$, distributed earnings $\left(\mathrm{DE}_{\mathrm{i}, \mathrm{t}}\right)$ as the distributed earnings of the firm $i$ at time $\mathrm{t}$, size $\left(\mathrm{S}_{\mathrm{i}, \mathrm{t}}\right)$ as the total sales of the company, changes in the distributed earnings $\left(\Delta \mathrm{DE}_{\mathrm{i}, \mathrm{t}}\right)$ as $\mathrm{DE}_{\mathrm{i}, \mathrm{t}}-\mathrm{DE}_{\mathrm{i}, \mathrm{t}-1}$ and in last year's dividend $\left(\Delta D_{t}\right)$ as $\Delta D_{t}-\Delta D_{t-1}$.

\section{THE MODEL}

In order to proceed the analysis of the data econometric methods designed for panel data were used. The use of panel data models is a powerful research instrument, since it combines the cross-sectional data with timeseries data, and provides results that could not be estimated and studied if only time-series or cross-section data were used. A general model for panel data that allows the researcher to estimate panel data with great flexibility and formulate the differences in the behavior of the cross-section elements is theoretically as follows ${ }^{8}$ :

$$
y_{i t}=x_{i t}^{\prime} \beta+z_{i t}^{\prime} a+\varepsilon_{i t}
$$

where $y_{i t}=$ is the dependent variable, $x_{i}=$ is the matrix with the independent variables, and $z_{i}=$ is a matrix which contains a constant term and a set of individual or group specific variables, which may be observed or unobserved. This model is a classical regression model. If the matrix $z_{i}$ can be observed, for all individuals, then the least square method gives efficient and consistent estimators.

The pooled regression considers that $z_{i}$ contains only a constant term. In this case the ordinary least square method provides an efficient and consistent estimate for the $\beta$ and the $\alpha$ coefficients. If $z_{i}$ is unobserved and

\footnotetext{
${ }^{7}$ see M. Bennett and R. Donnelly (1993)

${ }^{8}$ For more information see Greene (2003).
} 
correlated with the independent variables then the least squares estimator of $\beta$ is biased and inconsistent, as a consequence of an omitted variable. The fixed effects method takes those problems into account and gives an unbiased and consistent estimator of $\beta$ and $\alpha$. If the unobserved individual effects can be formulated, and under the assumption that these observations are uncorrelated with the independent variables, the econometric model can be estimated by the random effects method.

This paper tests the explanatory power of a model based on the distributed earnings of the firm and its size and examines a previous result for the Greek market, that firms have a long run target payout ratio, not only by the known changes in dividend parameter but also by the changes in distributed earnings. The econometric presentation of the model is:

$$
D_{i t}=a_{i}+\beta_{1} D E_{i t}+\beta_{2} S_{i t}+\beta_{3} \Delta D_{i, t}+\beta_{4} \Delta D E_{i t}+\varepsilon_{i t}
$$

where $D_{i t}=$ the dividend of the firm $i$ at time $t, D_{i t}=$ the distributed earnings of the firm $i$ at time t, $\Delta D_{i t}=D_{i t}-D_{i, t-1}$ the change between the dividend at time $t$ and time $t-1$, for the firm $i, \Delta D_{i t}=D_{i t}-D_{i, t-1}$ the change between the distributed earnings at time $\mathrm{t}$ and time $\mathrm{t}-1$, for the firm $\mathrm{i}$ and $\varepsilon_{\mathrm{it}}=$ the error at time $\mathrm{t}$.

\section{EMPIRICAL RESULTS}

Tables 1 to 3 present the estimations of the econometric model presented in equation 5 . In order to run and improve the performance of the models they were estimated by using the total, the fixed effects and the random effects model. In contrast with previews analyses in dividend policy for the Greek market the random effects model provide us with high $\mathrm{R}^{2}$ and all the independent variables were found to be significant except for the constant term that was not significant even for $90 \%$ level of confidence. The insignificance of the constant term raises a point against the use of the constant term in the model. In order to test this finding the total model was estimated with and without the constant term. The estimates from the fixed effects model proved to be more appropriate.

The results from the Random Effects model are presented in the Table 1.

Table 1

\begin{tabular}{|c|c|c|c|c|}
\hline Model & \multicolumn{4}{|c|}{$D_{i t}=a_{i}+\beta_{1} D E_{i t}+\beta_{2} S_{i t}+\beta_{3} \Delta D_{i, t}+\beta_{4} \Delta D E_{i t}+\varepsilon_{i t}$} \\
\hline Method & \multicolumn{4}{|c|}{ Random Effects (GLS, Variance Components) } \\
\hline & Coefficients & t-Stat. & Prob. (t - Stat.) & Stand. Error \\
\hline Constant & $-837,882.3$ & -1.053 & 0.292 & $795,953.4$ \\
\hline $\mathbf{D E}_{t}$ & 0.197 & 18.500 & 0.000 & 0.011 \\
\hline$S_{t}$ & 0.043 & 19.601 & 0.000 & 0.022 \\
\hline$\Delta D_{t}$ & -0.551 & -7.846 & 0.000 & 0.031 \\
\hline$\Delta \mathrm{DE}_{\mathrm{t}}$ & -0.134 & -11.917 & 0.000 & 0.011 \\
\hline $\mathbf{R}^{2}$ & \multicolumn{4}{|c|}{0.946} \\
\hline$R^{2}$ adj. & \multicolumn{4}{|c|}{0.946} \\
\hline S.E. & \multicolumn{4}{|c|}{$8,108.559$} \\
\hline $\begin{array}{l}\text { S: Genere } \\
\text { is the sq }\end{array}$ & quare & & & \\
\hline
\end{tabular}

The results with the random effects total model indicate that the $94.6 \%$ of the amount of dividend paid by the firm can be explained by the variables tested. It is obvious that the constant term is not statistically significant. On the contrary all the independent variables proved to be very useful and to have very high $\mathrm{t}-\mathrm{statistics,}$ which indicate that are statistically significant in level of confidence $95 \%$. 
The same econometric model was estimated with the Total model and it is presented in Table 2. Table 2 presents the estimation of the model 5 without the constant term. The constant term was omitted because the results of the regression were better than those obtained when the constant term was included. In more detail the $\mathrm{R}^{2}-$ adjusted and the $\mathrm{F}-$ statistic of the model were $78.7 \%$ and 657.6 respectively.

Table 2

\begin{tabular}{|c|c|c|c|c|}
\hline Model & \multicolumn{4}{|c|}{$D_{i t}=\beta_{1} D E_{i t}+\beta_{2} S_{i t}+\beta_{3} \Delta D_{i, t}+\beta_{4} \Delta D E_{i t}+\varepsilon_{i t}$} \\
\hline Method & \multicolumn{4}{|c|}{ Total (GLS, cross section weights) } \\
\hline & Coefficients & $\mathbf{t}-$ Stat. & Prob. (t - Stat.) & Stand. Error \\
\hline $\mathbf{D E}_{\mathrm{t}}$ & 0.202 & 38.356 & 0.000 & 0.005 \\
\hline $\mathbf{S}_{\mathrm{t}}$ & 0.032 & 79.159 & 0.000 & 0.000 \\
\hline$\Delta \mathbf{D}_{\mathrm{t}}$ & -0.442 & -15.212 & 0.000 & 0.029 \\
\hline$\Delta \mathbf{D E}_{\mathrm{t}}$ & -0.137 & -14.983 & 0.000 & 0.009 \\
\hline $\mathbf{R}^{2}$ & \multicolumn{4}{|c|}{$\frac{1}{0.831}$} \\
\hline $\mathbf{R}^{2}$ adj. & \multicolumn{4}{|c|}{0.831} \\
\hline F - Stat. & \multicolumn{4}{|c|}{$1,173.8$} \\
\hline S.E. & \multicolumn{4}{|c|}{$13,913,989$} \\
\hline $\begin{array}{l}\text { GLS: Genera } \\
\text { S.E. is the squ }\end{array}$ & $\begin{array}{l}\text { Square } \\
\text { of the reg }\end{array}$ & & & \\
\hline
\end{tabular}

The results of the total model did not improve our first estimation. The $\mathrm{R}^{2}$ is now lower and the square error of the regression is bigger than that of random effects model presented in Table 1. The most important results are that all the explanatory variable are significant in $95 \%$ and the $\mathrm{R}^{2}$ without the constant term is $5 \%$ greater than the one with the constant term. Comparing the results presented in Tables 1 and 2 we see that the random effects model has a greater explanatory power but with the constant term insignificant. There are many possible reasons for this, the most probable one is that there are individual effects in the panel data. At this point, the set of the assumption of the random effects model was relaxed (i.e. that the individual or group effects are known and can be formulated) and the model was estimated by the Fixed Effects model. The results are presented in Table 3.

Table 3

\begin{tabular}{|c|c|c|c|c|}
\hline Model & \multicolumn{4}{|c|}{$D_{i t}=\beta_{1} D E_{i t}+\beta_{2} S_{i t}+\beta_{3} \Delta D_{i, t}+\beta_{4} \Delta D E_{i t}+\varepsilon_{i t}$} \\
\hline Method & \multicolumn{4}{|c|}{ Fixed Effects (GLS, cross section weights) } \\
\hline & Coefficients & t-Stat. & Prob. (t - Stat.) & Stand. Error \\
\hline $\mathbf{D E}_{\mathrm{t}}$ & 0.182 & 22.268 & 0.000 & 0.008 \\
\hline $\mathbf{S}_{\mathrm{t}}$ & 0.034 & 30.707 & 0.000 & 0.001 \\
\hline$\Delta \mathbf{D}_{\mathrm{t}}$ & -0.478 & -24.174 & 0.000 & 0.019 \\
\hline$\Delta \mathbf{D E}_{\mathrm{t}}$ & -0.116 & -18.949 & 0.000 & 0.006 \\
\hline $\mathbf{R}^{2}$ & \multicolumn{4}{|c|}{0.961} \\
\hline $\mathbf{R}^{2}$ adj. & \multicolumn{4}{|c|}{0.951} \\
\hline F-Stat. & \multicolumn{4}{|c|}{$4,687.2$} \\
\hline S.E. & \multicolumn{4}{|c|}{$7,367,659$} \\
\hline
\end{tabular}

The estimation of the econometric model by the fixed effects method improved our results. The explanatory power of the fixed effects model increased to $95.1 \%\left(\mathrm{R}^{2}\right.$ - adjusted) and the $\mathrm{F}$ - Statistic appears even better. In addition, all the coefficients are statistically significant in level of confidence $95 \%$. 
The results from the three econometric models (i.e. total, random and fixed effects models) provide us with very important remarks. All the independent variables are statistically significant and their signs remain unchanged for all the estimated models. As it was expected, the distributed earnings of the firm are positively related with the dividend of the firm. The greater amount from the earnings that are going to be distributed the greater the dividend. In the case where the earnings of the firm are lower than the last years earnings, the firm will adjust the dividend accordingly. The positive sign in the size variable expresses the trend of bigger and stronger firms to distribute higher dividend than the small ones. That makes sense since powerful and big companies have better access in the market and can raise funds easier than smaller companies, thus they can allocate more money to their investors.

Concerning the variables that test the long run target dividend payout ratio two major observations have to be made, both variables are statistically significant with negative signs. As far as the changes from last year's dividend is concerned, the negative sign indicates that the firm has a constant payout ratio. Considering an increase from the last year's dividend, the increase will have negative impact on this year's dividend; this deduction constitutes the will of the firm to not change its dividend policy and to obtain the same dividend payout ratio. This result is consistent with the findings of Lintner (1956) that managers do not change the firm's payout policy in the short run. The second evidence that supports Lintner's findings is the negative sign in the variable that measures the changes in the distributed earnings of the firm. A positive change in distributed earnings has a negative impact on the distributed dividend. This result straightens the previous conclusion that even thought firms are increasing their earnings they try not to change their dividend policy, at least for the short - run.

The above findings are consistent with the previous works of Vasiliou \& Eriotis conducted for the Greek market during the same period. Both results support the existence of target long - run payout ratio and that dividend in year $t$ depends on distributed earning and size of the firm plus an adjustment from the last year's dividend and distributed earnings of the firm.

\section{CONCLUSIONS}

The empirical findings of the model presented in this paper suggest that distributed earnings and size of firm include an indication about the firm's dividend. This model also tested previous results of the Greek market that Greek firms have a long run target dividend payout ratio. The model includes two variables that determine the corporate dividend decisions, the distributed earnings and the size of the firm. The results of this model provide a significant estimation with explanatory power of $95,4 \%$ (when cross section weights and characteristic groups are taken into account). This model's evidence suggests that the dividend at time $t$ can be expressed as the long-run target dividend payout represented by both the changes in dividend and in distributed earnings and an adjustment to distributed earnings and last year's dividend of the firm at time t. Thus, on the evidence so far available, it appears that the Greek sample companies have a general dividend policy: to distribute, each year, dividend according their target payout ratio, which is adjusted to distributed earnings and size of the firm.

\section{REFERENCES}

1. Allen F. and R. Michaely, (1995), "Dividend Policy", in Handbooks in Operations Research and Management Science, vol. 9, Finance, R. A. Jarrow, V. Maksimovic and W. T. Ziemba (eds.), North Holland, pp. 793- 837.

2. Barclay M. J. , C. W. Smith and R. L. Watts, (1995), “The Determinants of Corporate Leverage Policy and Dividend Policy", Journal of Applied Corporate Finance, Bank of America, Vol. 7, No 4, Winter pp. 4 19.

3. Bennet, M. and R. Donnelly, (1993), "The determinants of Capital Structure: Some UK Evidence", British Accounting Review, pp. 43 - 59.

4. Brittain, J. (1966), Corporate Dividend Policy, The Brookings Institution. Washington.

5. Brittain, J. (1964), "The Tax Structure and Corporate Dividend Policy", American Economic Review, pp. $272-287$.

6. Eriotis N. and D. Vasiliou, (2003), "Dividend Policy: An Empirical Analysis of the Greek Market", International Business \& Economics Research Journal, 2004, vol. 3, no. 3, pp. 49-57. 
7. Frankfurter G. M. and B. G. Wood, Jr., (2002), "Dividend Policy Theories and their Empirical Tests", International Review of Financial Analysis, vol. 11, issue 2, pp. 111-138.

8. Fama E. F. and H. Babiak, (1968), "Dividend Policy: An Empirical Analysis", Journal of the American Statistical Association, 63, pp. 1132 - 1161.

9. Gordon M. J., (1963), “Optimal Investment and Financing Policy”, Journal of Finance, May, pp. 264-272.

10. Greene, W. H. (2003), Econometric Analysis, $5^{\text {th }}$ Ed., Prentice Hall.

11. Joannos J. and N. Filippas, (1997), "Dividend Policy of Firms listed in The Athens Stock Exchange: An Empirical Analysis", Spoudai, vol. 47, No. 3-4, pp.249 - 285, (in Greek).

12. Lintner J., (1962), "Dividends, Earnings, Leverage, Stock Prices, and the Supply of Capital to Corporations", Review of Economics and Statistics, August, pp. 243-269.

13. Lintner, J. (1956), "Distribution of Incomes of Corporations among Dividends, Retained Earnings and Taxes", American Economic Review, May, pp 97 - 113.

14. Lintzenberger R. H. and K. Ramaswamy, (1979), "The Effects of Personal Taxes and Dividends on Capital Asset Prices", Journal of Financial Economics, June, pp. 163-196.

15. Miller M. and F. Modigliani, (1961), "Dividend Policy, Growth, and the Valuation of Shares", Journal of Business, October, pp. 411-133.

16. Patsouratis, V. (1989), "Corporate Taxation and Dividend Behavior: An Empirical Analysis", Greek Economic Review, pp. 323 -338.

17. Short H., H. Zhang, and K. Keasey, (2002), "The Link Between Dividend Policy and Institutional Ownership", Journal of Corporate Finance, 8, pp. 105-122.

18. Vasiliou D. and N. Eriotis, (2003), "The Determinants of Dividend Policy: Some Greek Data", paper presented in the European Applied Business Research Conference, Venice, Italy, 2003, pp. 1-5. 